\title{
Ramification of lithic production and the search of small tools in Iberian Peninsula Middle Paleolithic
}

\author{
Joseba Rios-Garaizar ${ }^{\text {a, }}{ }^{*}$, Aleix Eixea ${ }^{\text {b }}$, Valentín Villaverde ${ }^{b}$ \\ a Traceology Group, Consorcio CENIEH (Centro Nacional de Investigación sobre la Evolución Humana), Paseo Sierra de Atapuerca s/n, 09002 Burgos, Spain \\ ${ }^{\mathrm{b}}$ Departament de Prehistòria i Arqueologia, Universitat de Valencia, Spain
}

\section{A R T I C L E I N F O}

Article history:

Available online 2 August 2014

\section{Keywords:}

Iberian Peninsula

Late Middle Paleolithic

Ramified production

Small flake

Lithic technology

Neandertal

\begin{abstract}
A B S T R A C T
The notion of recycling and it relationship with ramified productions and small tool production in Late Middle Paleolithic from the Iberian Peninsula are investigated. Results from Amalda, Axlor, Peña Miel, and Quebrada show that the production of small tools is one of the principal objectives of lithic provisioning in these sites. Whereas in Axlor and Amalda, this is achieved through the ramification of production, due to the remoteness of flint sources, in Quebrada, where raw material sources are closer, small flakes are obtained at the end of Levallois production. The implications for Neandertal society organization of this small tool production is discussed, and its evolution is observed from a diachronic perspective.
\end{abstract}

(C) 2014 Elsevier Ltd and INQUA. All rights reserved.

\section{Introduction}

The separation of lithic assemblages into tight technological categories (cores, flakes, byproducts, tools, waste) is a common analytical procedure, but it should be kept in mind that such categories did not exist among Paleolithic hunter-gatherers, or at least, that they were not as tight. The passage of artifacts from one category to another is observed in most archaeological assemblages (tools/cores, byproducts/retouched tools, abandoned/re-used tools, etc.), meaning that it was quite usual behavior. The analysis of this evidence can be very informative about the nature of lithic provisioning and management strategies, which is one of the best ways to understand crucial aspects of the socio-economical organization of paleolithic hunter-gatherer societies.

One of the most characteristic features of Western European Middle Paleolithic lithic assemblages is the existence of tools or raw flakes transformed into cores to produce new generation supports (ramification- (Bourguignon et al., 2004)). This is also the case in many of the Late Middle Paleolithic assemblages from Iberian Peninsula, but is not as common in the regional Early Middle Paleolithic (see for example (Rios-Garaizar et al., 2011). The ramification of production is related with mobility and the need for increment raw material productivity, but also with the need of small tools for specific activities. It can happen as an immediate solution to fulfill a concrete need or it can be a systematic strategy fully

\footnotetext{
* Corresponding author.

E-mail addresses: jorios76@gmail.com, joseba.rios@cenieh.es (J. Rios-Garaizar).
}

integrated in Neandertal technological systems. This ramification processes can be quite complex, including not only real recycling, understood as radical change of blank function (for example a tool transformed into core), but purposely made flakes to be exploited as cores, or integrated core-like exploitation within the resharpening process of some kinds of tools (e.g. Quina side scrapers).

Systematic application of ramified production suggests not only the existence of complex and planned tool provisioning strategies, but also the existence of structured productive processes where these new generation tools are integrated. This paper will determine if there was systematic ramified production in the Late Middle Paleolithic, through the analysis of several Iberian Peninsula assemblages. The existence of ramified production, its technological regularity, the weight of this production inside the assemblage, the use/transformation of new generation tools, and the relationship with raw material procurement and mobility strategies will be used to determine the significance of this kind of technological behavior.

\section{Iberian Peninsula, Late Middle Paleolithic}

The Iberian Peninsula is the southwesternmost region of Europe (Fig. 1). It has a very diverse geography, where several major regions can be recognized: Northern Cantabrian region, Castilian Plateau, Atlantic coastal region, Ebro Valley and Mediterranean coastal region. Each of these regions had particular climatic and environmental conditions during the Upper Pleistocene (UP), with a more or less continuous population of Neandertals during MP and modern humans in UP. 


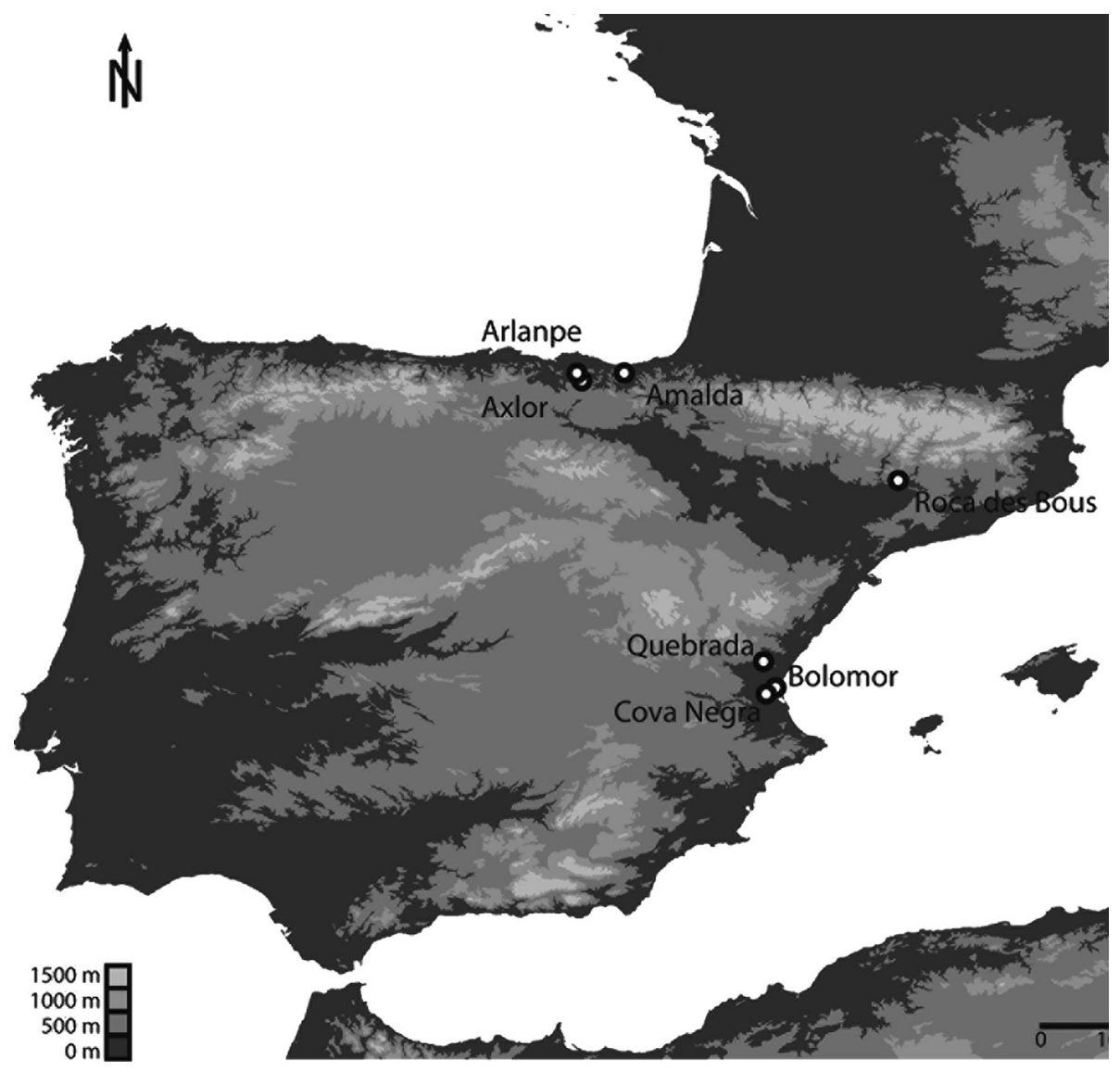

Fig. 1. Map of the Iberian Peninsula with the location of the sites mentioned in the text.

The Middle Paleolithic record is more abundant at the end of the period ca. 60-40 ka BP. The Iberian Peninsula is considered one of the last refugia of Neandertal populations (Zilhão, 2006; Finlayson et al., 2008; Higham et al., 2011). Recently some of the late dates of Mousterian assemblages in this region have been discussed (Wood et al., 2013) but, roughly, it can be said that there is some persistence of Neandertal groups after ca. $40 \mathrm{ka} \mathrm{BP}$, after the first Upper Paleolithic assemblages in the northern Iberian Peninsula (Martínez-Moreno et al., 2010; Wood et al., 2014).

Although no detailed synthesis is available for lithic technology evolution during the Late Middle Paleolithic in this macroregion, some insights can be provided. One of the major features of this period is the high degree of variability than can be observed in settlement strategies, raw material provisioning, and lithic tool production and use (Carrión Santafé et al., 2008; Rios-Garaizar, 2008; Torre et al., 2013).

Raw material provisioning usually shows high dependence on the local sources. This is quite visible in areas without flint sources, because this material tends to appear only in small percentages (Torre et al., 2013). Nevertheless this is not a fixed rule and raw material transport can be observed, even comprising long distance displacements. In some regions, e.g. Eastern Cantabria, flint transport over distances more than $30 \mathrm{~km}$ is the rule (Rios-Garaizar, 2012a). Raw material provisioning strategies seem to be driven by the specific necessities generated by Neandertal group mobility, intensity and duration of settlements, and by specific functional needs.

Regarding lithic production, variability is also the rule. Discoidal, Levallois and Quina are the most common methods, in all variations, used by Neandertal groups. The absence of bifacial technology which characterizes some late Middle Paleolithic assemblages in France and Northern Europe (Ruebens, 2013) is noteworthy. The Quina method is almost absent from central. southern and western Iberian Peninsula, but is present in some sites in the Mediterranean coastal region (Cova Negra- (Villaverde, 1984; Bourguignon, 1997)), in the Meseta (Navazo and Díez, 2009; García-Moreno et al., in press) and many sites in the Cantabrian Region (Rios-Garaizar, 2005; Garcia Garriga et al., 2012). Levallois and Discoidal methods, despite the existence of some problems to define clearly the border between them, appear elsewhere (Casanova et al., 2008). A certain correlation between the quality of raw material and the application of Levallois technology can be established, but it has not been fully investigated. Tool production shows less variability. Side scrapers and denticulates dominate the toolkit, but important differences regarding the size of lithic tools and the morphology of used edges can be documented (Rios-Garaizar, 2012a). This variability observed in lithic management strategies can be extensible to other expressions of Neandertal behavior, as for example bone tool use (Mozota, 2012), fire use (Courty et al., 2012; Mallol et al., 2012; Uzquiano et al., 2012), site structuration (Vaquero et al., 2012) or subsistence strategies (Altuna, 1989; Yravedra Sainz de los Terreros, 2003).

\section{Case studies}

3.1. Quina ramification process in Axlor rockshelter (Northern Iberian Peninsula)

The site of Axlor was excavated initially by Barandiarán (1980), and later by J. E. González, J. J. Ibañez and J. Rios-Garaizar (González Urquijo et al., 2006). Both excavations produced different 
stratigraphic sequences, the first one named with roman numerals (I-VIII) and the second one with letters (A to P). The correlations between old and new sequences, although they have been excavated in the same area, are not always easy. The upper levels III-V correspond to B-D levels, but no direct correlation is possible because the original excavation levels cut across different stratigraphic units. Levels E-F correspond to level VI, M to VII, and N to VIII. Only the B level has a reliable ${ }^{14} \mathrm{C}$ AMS date of ca. 45,950 cal BP $(42,010 \pm 1280$ BP, Beta 144262) (González Urquijo et al., 2005) corresponding with the $\mathrm{H} 5$ event. Levels $\mathrm{D}$ and $\mathrm{F}$ yielded minimum ages of $>43,000$ and $>47,500$, respectively (Rios-Garaizar, 2012a).

Levels $B$ and D represent different occupations with different intensities, D being a thick palimpsest while B represents limited occupation. Faunal assemblages reveal an intense exploitation of carcasses, with the most represented species being Bos/Bison, Capra pyrenaica and Cervus elaphus (Castaños, 2005). Lithic assemblages from these levels have been published in detail (Rios-Garaizar, 2012a, 2005) (Fig. 2). Both display similar technological and typological features, although some subtle differences have been observed. Raw-material composition is characterized by a high proportion ( $>80 \%$ ) of flint. This raw material is not present at the site, so the inhabitants of the cave transported it from different sources located more than $30 \mathrm{~km}$ far away. Identified flint sources are Flysch, Urbasa, and Treviño. The first one, the most abundant one, is present in several points along the current seashore, more than $30 \mathrm{~km}$ north, with Kurtzia being the most important outcrop (Tarriño Vinagre, 2006). Treviño and Urbasa are south of the site, between 45 and $70 \mathrm{~km}$ from Axlor. Local raw materials (mudstone and quartz) were scarcely used for the production of large cutting tools.

Lithic assemblages are dominated by thick Quina side scrapers and rejuvenation flakes. Quina side scrapers are intensely curated at the site, producing a large amount of rejuvenation flakes, highly variable in both size and morphology. Quina rejuvenation is a complex procedure that includes different stages (Bourguignon, 1997, 2001): reflected flakes are obtained to create the typical Quina step retouch, overshot flakes are used to clean the retouched surface and to lower the edge angle, Clatonian flakes (flakes with broad platforms) are extracted to recover the plan convexity of the edge, Kombewa flakes (ventral flakes) are used to recover profile convexity, and finally (sometimes) lateral flakes (burin spalls) or flakes detached from the central ridge of the flake are obtained as more drastic reconfigurations of side scrapers. All these procedures create characteristic resharpening flakes that have been classified in different types (Bourguignon, 1997). Some of the resharpening flakes were selected for use as tools and some were even transformed into new side scrapers, denticulates, and lightly retouched flakes. The importance of this procedure in the configuration of the retouched toolkit is evident in that it constitutes $38.7 \%$ of the total in level D and $32.8 \%$ in level B. The analysis of the size of these retouched resharpening flakes and comparison with nonretouched ones has shown that there was a selection of the largest supports for this new generation tools. Comparison with the negatives in the abandoned Quina side scrapers showed clearly that these retouched resharpening flakes are clearly larger, suggesting that they were not obtained at the end of in situ abandoned Quina side scraper lives and thus they are not the product of a recycling of non usable tools. Two different scenarios are possible: one that the large side scrapers were exported from the site; or that these large resharpening flakes were produced elsewhere and introduced into the site. Analysis of the detachment angles of these resharpening flakes has shown that they do not necessarily imply a rupture of the resharpening process, because the two main types of resharpening flakes (reflected and overshot) are used alternatively to create the typical Quina side scraper edge, one for creating the step profile (reflected) and the other to clean the edge and recover the angle (overshot) (Rios-Garaizar, 2012a). The role of clatonian resharpening flakes is more controversial, because for some authors this implies a complete rupture of the resharpening process, with changes in hammer, knapping gesture and morphology of the edge, which are probably more related with purposeful exploitation of side scrapers as flake cores (Bourguignon, 1997, 2001). In the Axlor collection, clactonian flakes were also used to reconfigure side scraper edges which were too straight, creating a convexity similar to those used to extend the life of carinated end scrapers (Chiotti, 2000). The previous and posterior edge angles suggest that clactonian flakes, with protuberant bulbs, reduce significantly the side scraper edge angle, creating new possibilities for resharpening. Some of the Quina side scrapers recovered at the site show clactonian negatives made before the last resharpening event. In our opinion, this suggests that the obtaining of clactonian flakes is related not only with the intentional production of flakes, but also with the Quina side scrapers resharpening process.

There are two possibilities: Neandertals were recycling the abandoned resharpening flakes, choosing the largest ones, or they were integrating the production of large flakes, usable for other purposes, in the resharpening process. It is not easy to assess intentionality when dealing with lithic assemblages, but in this case the systematic use of resharpening flakes, and the selection of the largest ones speak against an idea of opportunistic reuse. Thus we can speak about a combined process of rejuvenation and exploitation of Quina side scrapers to curate them and obtain a new range of tools with different morpho-functional characteristics (Rios-Garaizar, 2008). The intensity of this systematic strategy is also viewed in the abundance of bone retouchers used with side scrapers to produce new flakes (Mozota, 2012). Similar procedures have been identified at other Quina Mousterian assemblages such as Marillac (Costamagno et al., 2006) and Chez-Pinaud (Soressi, 2004).

\subsection{Levallois ramification process in Axlor rockshelter (Northern Iberian Peninsula)}

Lower levels from Axlor have no numerical dating, but probably they formed during warmer climatic conditions than the upper levels (Rios-Garaizar, 2012a), which gives us a probable age estimation of ca. 55-50 ka cal BP (perhaps coinciding with D014-16). This levels is a palimpsest formed by discrete occupations structured around fireplaces (González Urquijo et al., 2006), where animal carcasses, basically C. pyrenaica and C. elaphus (Altuna, 1989), have been processed with less intensity than in the upper levels. This suggest that the occupations in these levels were more stable and structured, creating a sort of residential camp.

The lithic assemblage (Fig. 3) is formed by flint implements, representing more than half of all raw materials, basically transported from northern flint outcrops (Flysch variety). This flint arrived at the site as tools (side scrapers and points) and flakes, usually exhibiting Levallois features. Local raw-materials, mudstone and quartz, were exploited to obtain larger flakes. Mudstone has been exploited in situ following a Levallois strategy. Flint is transported to the site as flakes or retouched tools, and some of these have been knapped secondarily to produce small flakes. The production follows a Levallois recurrent centripetal system. The main flaking surface is placed on the ventral face and the production is initiated by the preparation of a platform by faceting, which can be also a retouched edge, and then the extraction of small kombewa flakes. In the moment that these cores were abandoned, they have small dimensions (around $30 \mathrm{~mm}$ ), and the last negatives were smaller than $20 \mathrm{~mm}$. The small Levallois flakes, accounting for roughly one quarter of the assemblage, have acute 

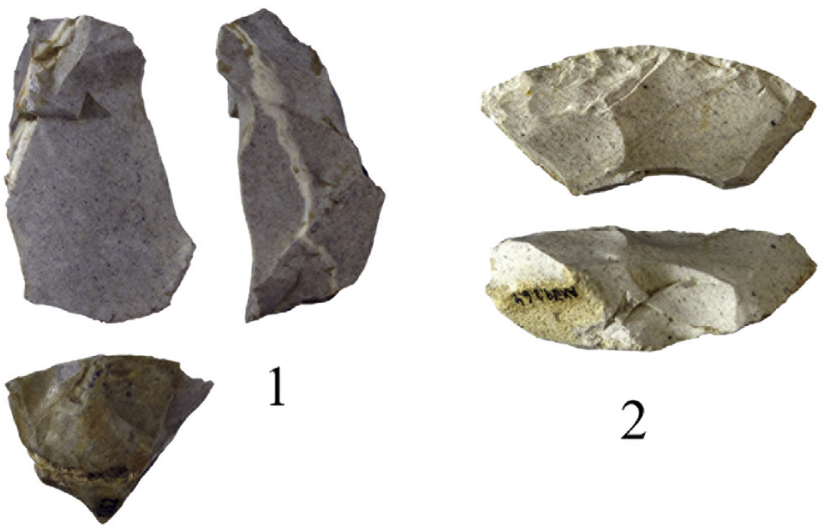

2

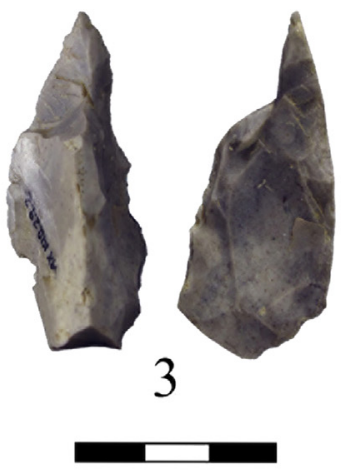

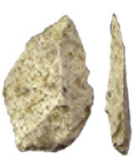

4

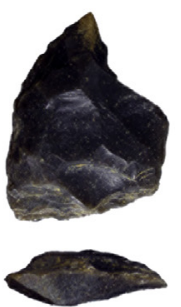

9

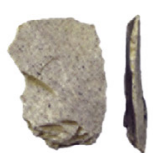

5

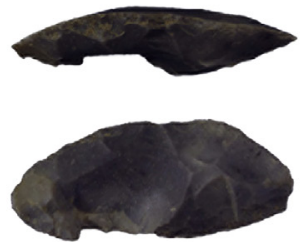

10

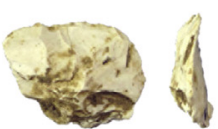

6

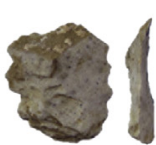

7

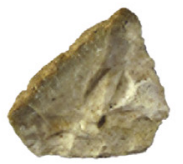

8
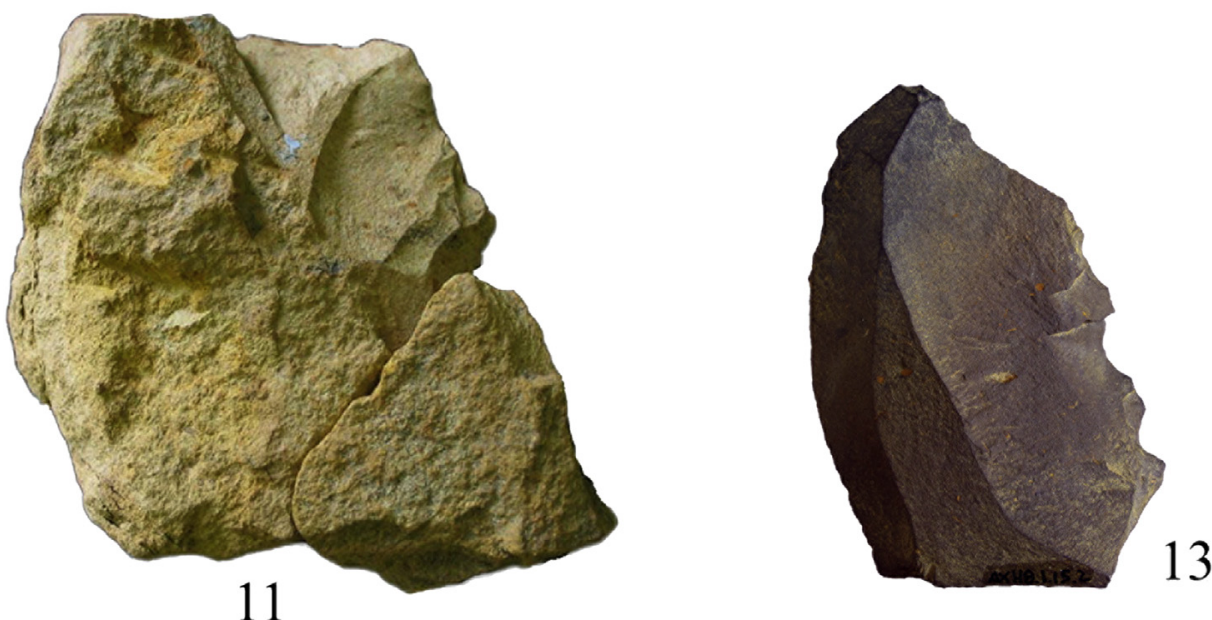

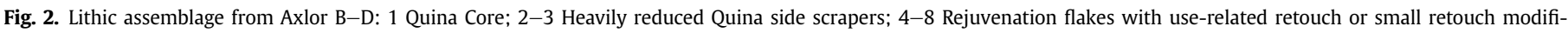
cations; 9-10 retouched rejuvenation flakes; 11 Refitted tobaceous mudstone core; $12-13$ Ferruginous mudstone elongated flakes.

edges, and some show slight transformation by retouch (15\%). The flakes selected to make these retouched tools were chosen from the largest ones. Many of the non-retouched small Levallois flakes, although there are no definitive use-wear results, show macro traces that indicate they were fully functional tools (Rios-Garaizar, 2012a).

This process can be described as a ramified Levallois production. The flint implements, which were transported to the site, were chosen by its properties as tools but also because they could also been exploited for obtaining new flakes, small and with acute edges, to fulfill new needs originated at the site. In this case, similarly to the upper levels of Axlor, Neandertal groups decided not to transport cores or heavy flakes. This created a deficit of large tools, which was solved by the use of local raw materials.

\subsection{Levallois ramification process in Amalda cave (Northern Iberian Peninsula)}

Amalda cave was excavated under the direction of J. Altuna (Altuna et al., 1990), revealing an Upper Paleolithic sequence with a 

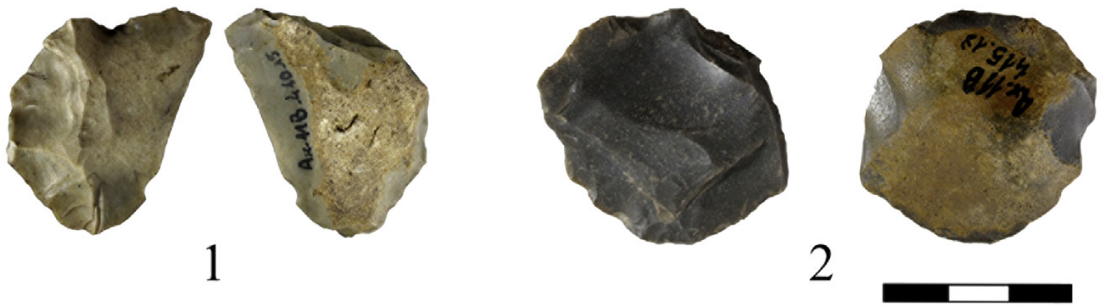

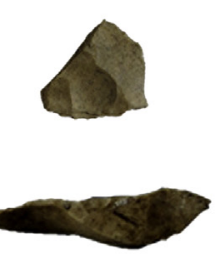

3

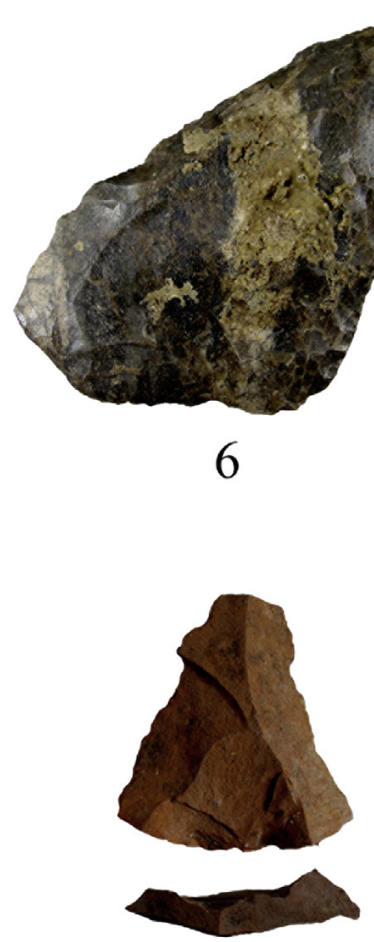

9

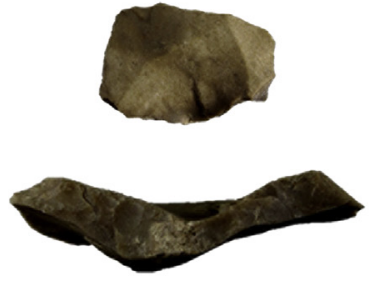

4
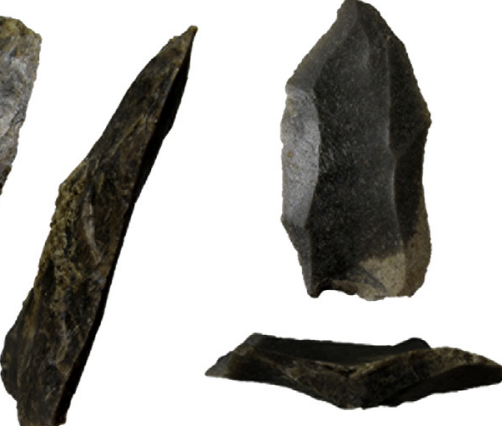

7

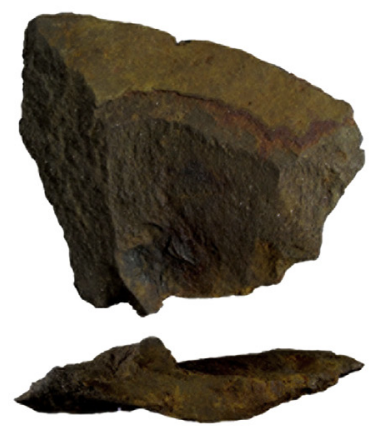

10

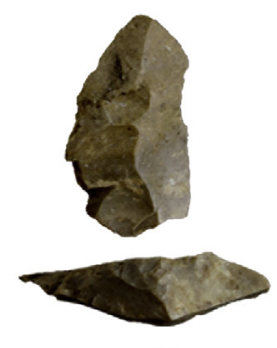

5
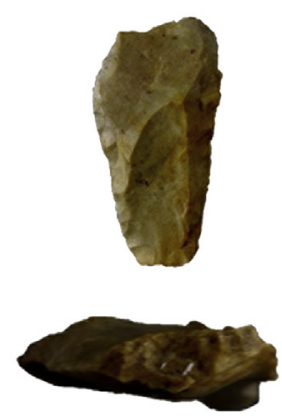

8

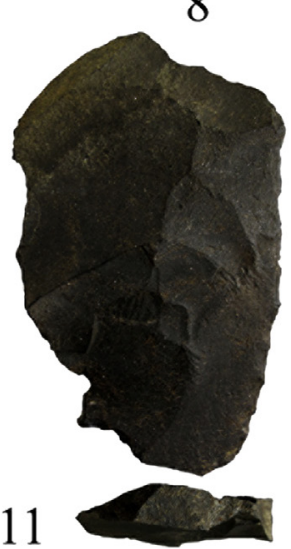

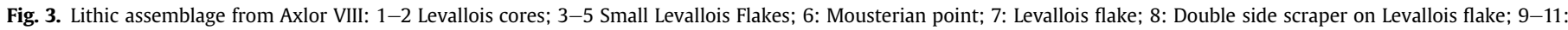
Flakes and tools made on ferruginous mudstone.

Mousterian level (level VII) at the base. This level has been assigned to MIS4 due to its stratigraphic position above Eemian sediments (MIS5e), but a more recent chronology can be envisaged (RiosGaraizar, 2012a). The faunal assemblage is composed mainly by chamois, which seems to have been transported almost entire to the site, while other herbivores are quite scarce. Despite the low frequency of carnivores (Altuna et al., 1990), recent studies suggest that they played an important role in faunal accumulations (Yravedra 2007), but this possibility has been rejected by Altuna and Mariezkurrena (2010). We have also proposed a complementary explanation suggesting a mixed taphocenosis (Rios-Garaizar, 2012b).

The lithic assemblage has been re-studied and published in detail (Rios-Garaizar, 2010, Fig. 4). Raw materials are dominated by flint, coming mainly from the flysch outcrops situated on the northern coast $(>15 \mathrm{~km})$. Occasionally, the Amalda inhabitants used also flint from the south, mainly Treviño and Urbasa flints $(45-75 \mathrm{~km})$. This material was introduced as already-made flakes and tools, mainly side scrapers. Some of these imported blanks and tools were exploited to obtain small flakes. Different methods were employed to produce them, including Levallois, Discoid, Kombewa, Quina and coup the tranchet. The Levallois system, as in the case of Axlor VIII, followed a recurrent centripetal organization which was initiated by the extraction of some kombewa removals to produce small and micro flakes. There are also examples of discoidal exploitation of flakes to obtain small flakes, some of them small pseudolevallois points. Quina ramification followed similar 

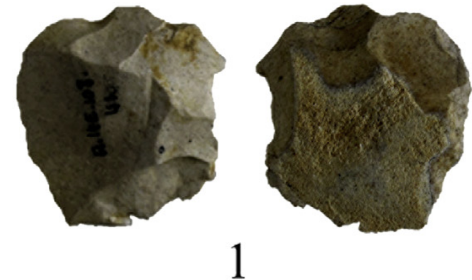

1

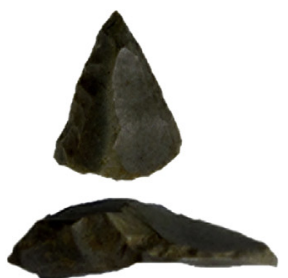

3
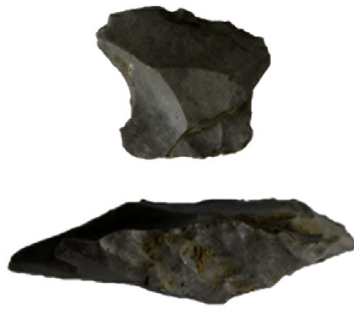

7

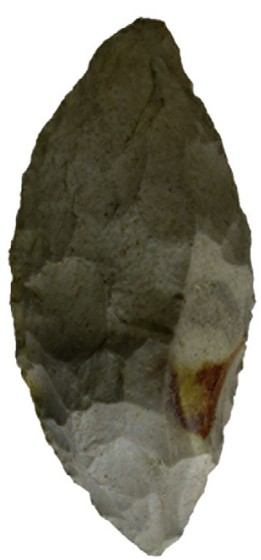

9

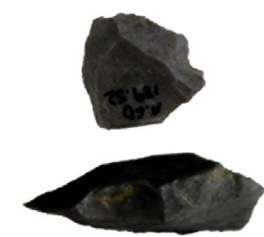

4
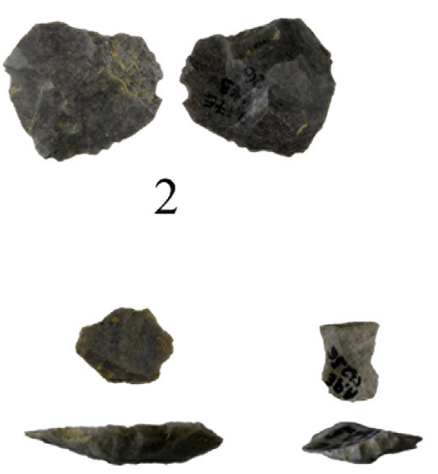

5
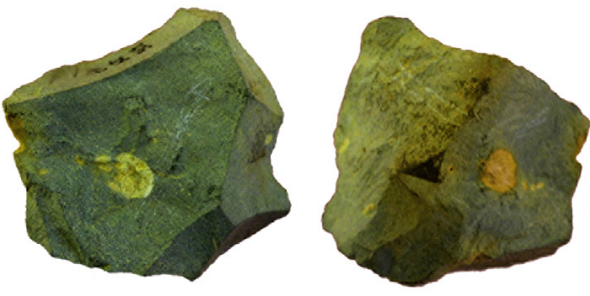

8
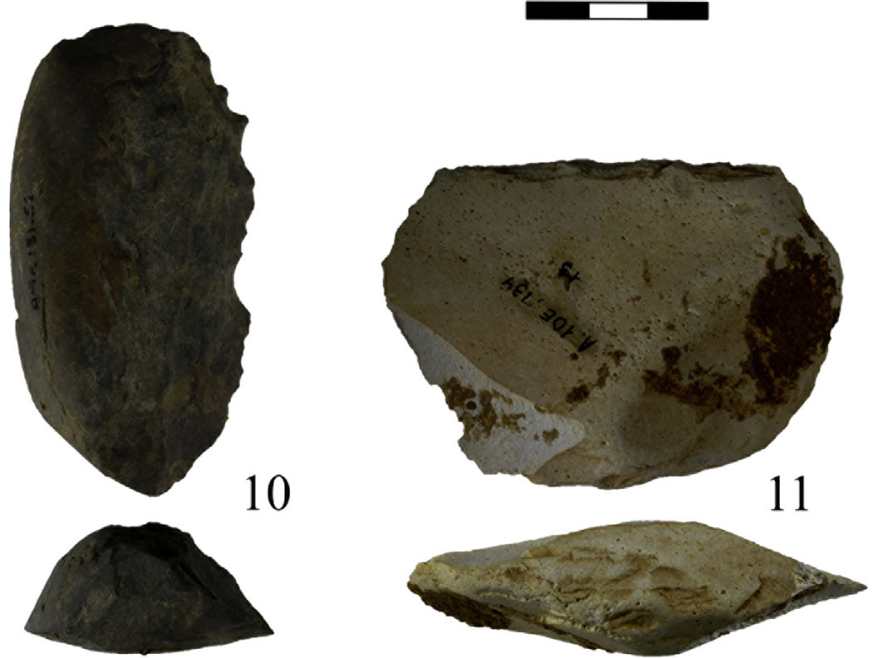

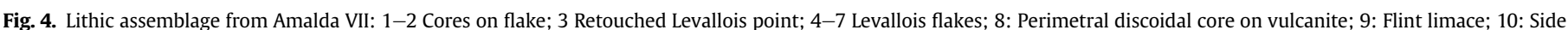
scraper on mudstone; 11: Side scraper on tobaceous mudstone.

procedures as described for Axlor B-D. Finally, there is a burin-like exploitation of some flakes, following the coup the tranchet (Bourguignon, 1992) system to obtain small, asymmetrical flakes. All these systems served to obtain small flakes, some of which were retouched and some used without transformation. Microlithic flakes (median: $13.3 \times 13.9 \mathrm{~mm}$ ) were retouched rarely (7.9\%), using abrupt retouch to create small gripping surfaces. Small flakes (median: $24.5 \times 19.6 \mathrm{~mm}$ ) were more frequently retouched $(33.3 \%$ ) as side scrapers, denticulates and even small Mousterian points. Use wear results have shown that these small and micro flakes were used, with little or no shaping by retouch, in different activities, mostly in the final phases of different productive processes (butchery, hide processing, wood working). This ramification of flint production created a clear deficit of large tools because there was a progressive reduction of the flint blank size. For that reason, local raw materials were exploited, even though they had poorer qualities for knapping or use. The most frequently used local rocks are tuffaceous mudstone, mudstone, and ophite, which were exploited following diverse methods. They applied a discoidal schema to produce large, asymmetrical, flakes with cutting edges and also bifacial shaping to produce bifacial tools (bifaces and cleavers).

The spatial distribution of lithic evidence in level VII suggests that there is a certain organization of space, with one central area where flake production and some heavy tasks where developed, two peripheral areas where varied activities were carried out, hide processing the most important activity in one, and a separate area where heavy tools were consumed, with a greater incidence of wood working (Rios-Garaizar, 2012a,b). The lithic provisioning system practiced in Amalda Middle Palaeolithic levels shows a high 
degree of integration between the transport of flint tools, the ramified production of small flint flakes, and the use of local raw materials to produce more massive tools.

\subsection{Non-ramified productions in Peña Miel (Ebro Valley)}

The cave of Peña Miel was excavated between 1980 and 1984 by P. Utrilla (Utrilla et al., 1987). It has two main Mousterian levels, e and g, dated around 50,000 and 40,000 BP (Montes et al., 2001). Level e shows a local quartzite dominated industry (65\%). Flint use is restricted to some imported blanks, cores, and tools coming from 25 to $60 \mathrm{~km}$ distant. In both levels, discoidal technology was applied to create triangular broad flakes, pseudolevallois points, in quartzite. Flint included some imported tools and flakes, of which some had been used as cores to produce small flakes following a micro discoidal schema. Retouched tools are dominated by side scrapers and denticulates. The presence of abundant bone retouchers suggests the high importance of configuration and resharpening of retouched tools, despite the low frequencies of resharpening flakes.

Differing from Axlor or Amalda in Peña Miel, there is no systematic ramified production, although there are few examples of cores on flakes. Tool provisioning relied almost exclusively on the medium quality quartzite that can be found near the site.

\subsection{Small flake, non-ramified production, in Abrigo de la Quebrada (Valencia)}

Abrigo de la Quebrada is a rockshelter situated near Valencia. The, excavations, still in progress, have revealed 8 archeological levels. Human occupation evidence is found in levels II-V, VII and VIII, and the most intensive occupations are those in levels III, IV and V (Eixea et al., 2011-2012). Level III has a date around 40,500 BP, and level IV around 43,930 (Eixea et al., 2011-2012; Villaverde et al., 2008). The lower levels (VII-VIII) probably date to MIS5.

Separated by sterile level VI, levels II-V and VII-VIII, must correspond to two different periods of occupation. The distributions of their respective archaeological contents show a clear difference in the density of finds. Level IV has a typical palimpsest structure characterized by the abundance of combustion features, knapping debris, and bone fragments. The analysis of the distribution of the least common elements yields a repetitive pattern of occupation characterized by high density scatters around the hearths. In level VII, the density of finds is much lower and the spatial structure is, therefore, better defined. Combustion areas, however, are restricted to the middle and lower spits of the level, opening the possibility that the lower density find scatters in the upper spits of this level relate to hearths located elsewhere at the site. The role played by natural and anthropogenic factors in the generation of these differences is the subject of ongoing research (Eixea et al., 2014b).

Faunal assemblage level IV is composed by Bovidae, Equidae, Cervidae, Leporidae, Testudinidae, Suidae, Rhinocerotidae and Canidae, where goat (Capra sp.), horse (Equus ferus) and red deer ( $C$. elaphus) are the best represented with a high level of postdepositional fragmentation, related to both heat and trampling, At levels VII-VIII, the fragmentation processes are less intense where medium and large size animals are concerned. The two units are rather similar in species composition, with Bovidae prevailing and both Equidae and Cervidae represented. The Canidae remains from level VII are of special interest because they point to the possibility of carnivore use of the shelter during periods of human abandonment In level VII, remains of Leporidae are present, but because of the calcium carbonate coating of bone surfaces, few carnivore and/or human processing and consumption marks could be identified (Sanchis et al., 2013; Eixea et al., 2014b).

In levels II and III, raw-material procurement was carried out within a radius of $10 \mathrm{~km}$ around the site, where Neandertals could find flint, quartzite, and limestone (Eixea, 2012; Eixea et al., 2014, 2011). Nevertheless some flint coming from sources situated more than $40 \mathrm{~km}$ distance is also present. In level II (Fig. 5), the technological features correspond to discoid and recurrent centripetal Levallois methods, whereas in level III (Fig. 6), Levallois exploitation is predominant. In both levels, the formal tools assemblage is dominated by lateral side scrapers, Levallois points, and Mousterian points. The degree of retouched tool curation, in comparison with described sites from Northern Spain, is very low, probably due to the proximity of raw material sources.

One of the main characteristics of lithic provisioning in Quebrada is the production of small flakes, obtained in the final stages of the progressive reduction of cores. There is no evidence of ramification, and the proximity of raw-material sources indicates that material exhaustion cannot explain the small size products. These small flakes were never retouched, and probably they were made for immediate utilization of a sharp, unmodified edge. Usewear analysis of a sample of 22 small flakes shows that a third of them were used, mostly in cutting activities, some of them directly related to butchery (Villaverde et al., 2012). This small flake production obtained from reduced-size cores has similar morphometric and functional features to micro-levallois coming from the ramified productions observed in Axlor or Amalda.

\section{Discussion}

The use of ramified production strategies falls into the logic of recycling. The application of these strategies in sites such as Axlor or Amalda is rather systematic, and thus it seems that is an important part of lithic provisioning systems. This implies a certain degree of planning, because they carefully choose the characteristics of the flint blanks and tools to be transported in order to be susceptible to such secondary use as cores. There is also evidence of more opportunistic, or at least, less systematic, ramification, as in the case of Peña Miel. In general, we can propose that the use of ramified strategies is more intense when high quality raw materials are distant, as in the case of Axlor or Amalda, but there are exceptions, as the case of Peña Miel where neandertals choose to use local quartzites instead of implementing a ramified strategy to assure the availability of flint from a considerable distance $(>20 \mathrm{~km})$. The necessity for flint, for whatever reason (quality of the edges, more control of tool design, etc.), was the reason driving the neandertal population to apply this kind of recycling.

The other important question that must be considered is that, as a rule, ramification produces small tools. The size of tools is sacrificed to obtain fresh flint edges. In Amalda or Axlor, there were only two possibilities to keep flint tools at hand, the first one was to curate the tools transported to the site, and the second one was to recycle some of these blanks into new tools. Size reduction of flint tools was almost unavoidable, and the need for larger tools, probably used in heavy duty tasks where the precision of flint edges were not so necessary, was fulfilled with local raw materials. In other sites, such as Quebrada, raw material is closer and there is no evidence of ramification. As has been proposed for other sites as Roca dels Bous (Mora et al., 2004; Casanova et al., 2008) or Pechl'Azé (Bordes, 1981; Dibble and McPherron, 2006), the production of small flakes at Quebrada was direct (not ramified) and fully intentional. It seems that the search of small tools is a fundamental part of the toolkit implementation. In all these sites, including those presented here, it has been demonstrated that small flake production is not only a strategy to avoid raw material exhaustion, but 

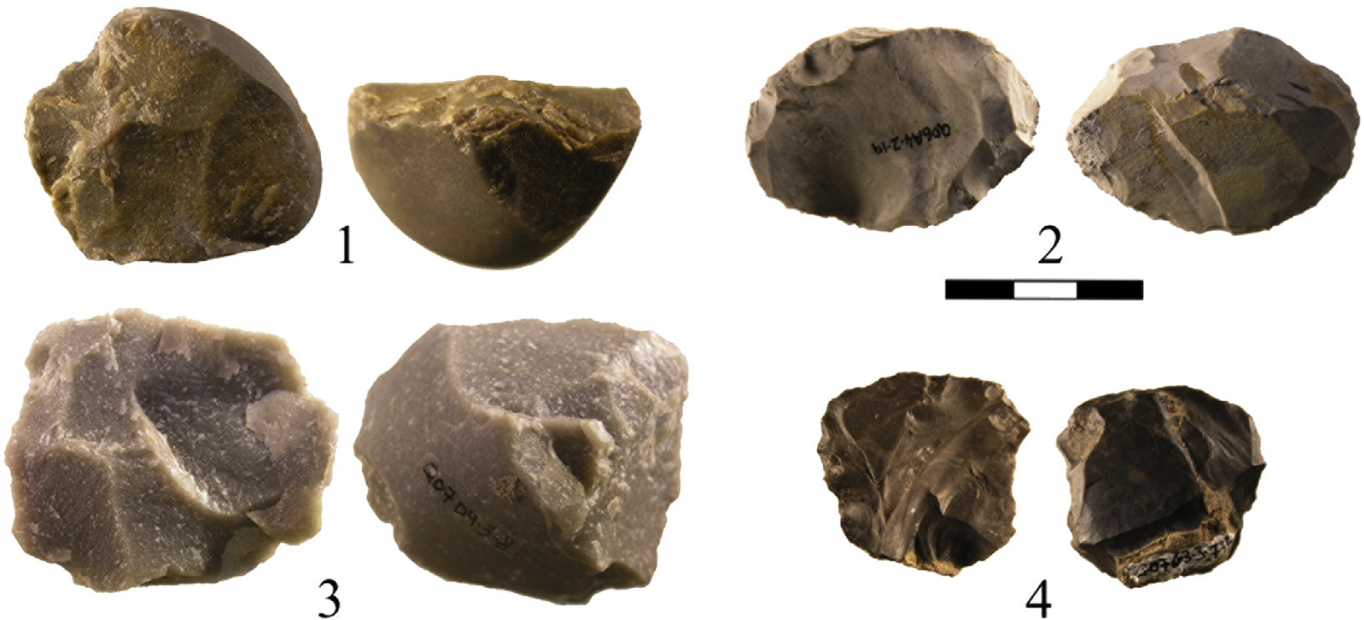

4

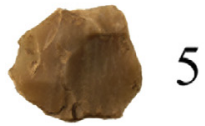

5
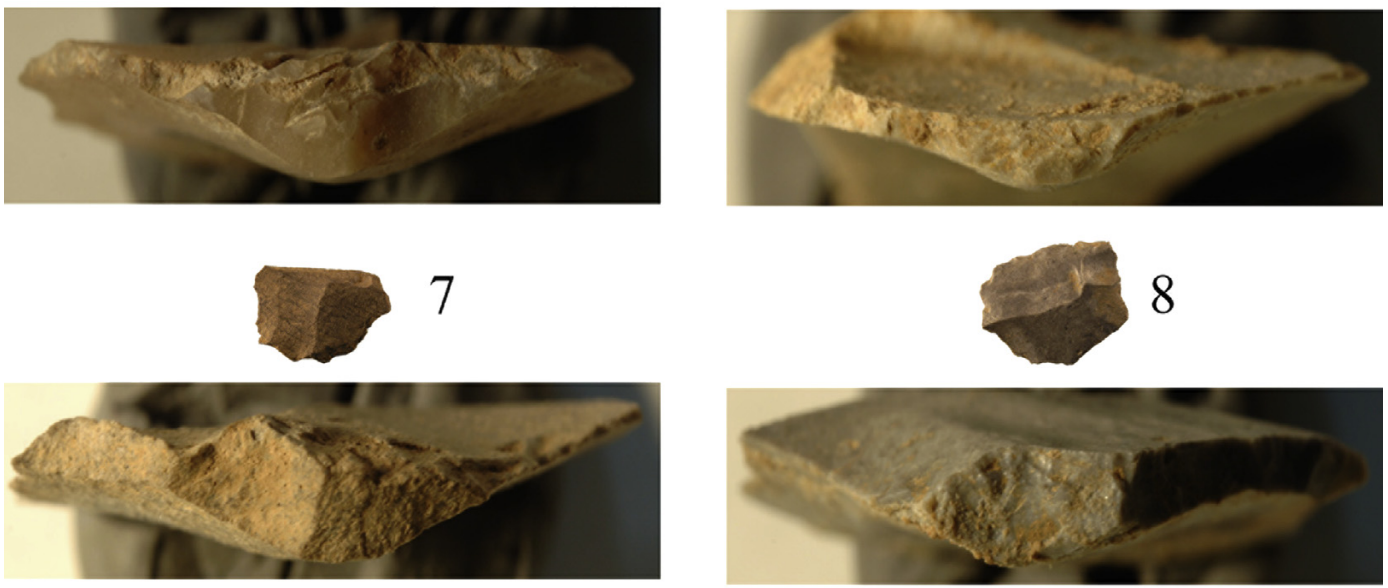

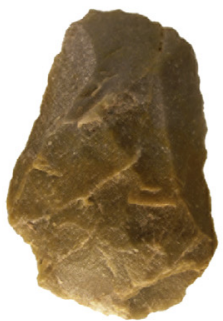

9

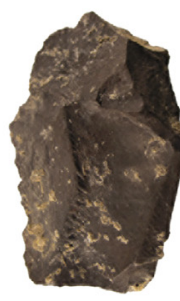

10

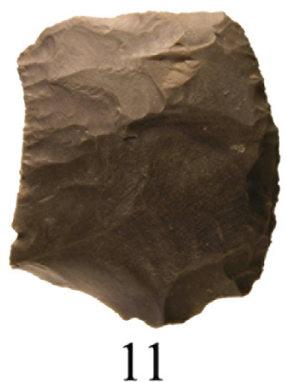

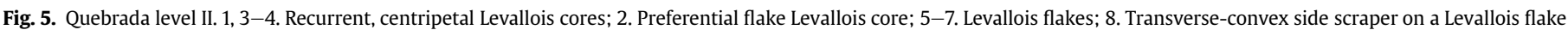

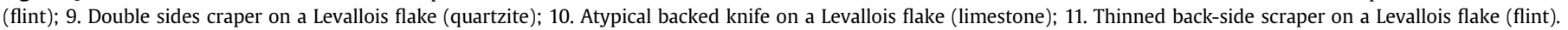

a strategy to obtain small flakes to fulfill concrete functional needs. Use-wear data from Amalda and Quebrada, although preliminary, shows that these small flakes were used in precision activities, taking advantage of precise gripping and the acute edges provided by flint. This suggests that, even in the case of ramified productions, small flake production was intentional and formed part of the tool provisioning systems in the Late Middle Paleolithic. We must interpret this search of small tools as a consequence of the increasing complexity of activity organization among the last
Neandertals. This need of small tools is clearly linked with the need of these kinds of tools, probably, as the use-wear suggest, for precision tasks. The existence of precision tools alongside heavy duty tools and normal tools is a reflection of complex organization of productive tasks, which had different and structured phases (Bourguingnon et al., 2004).

From a diachronic perspective, small size flake production is also present in Europe during the Lower Paleolithic (LP) and Early Middle Paleolithic (EMP) (Burdukiewicz and Ronen, 2003). In these 

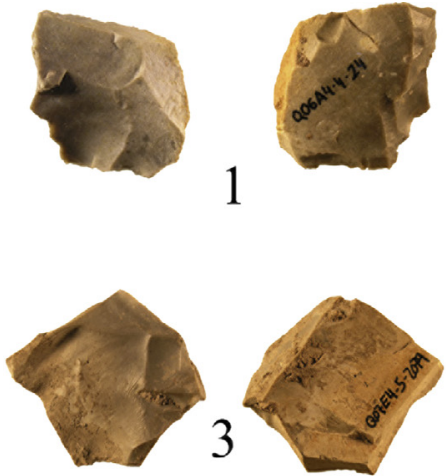

5
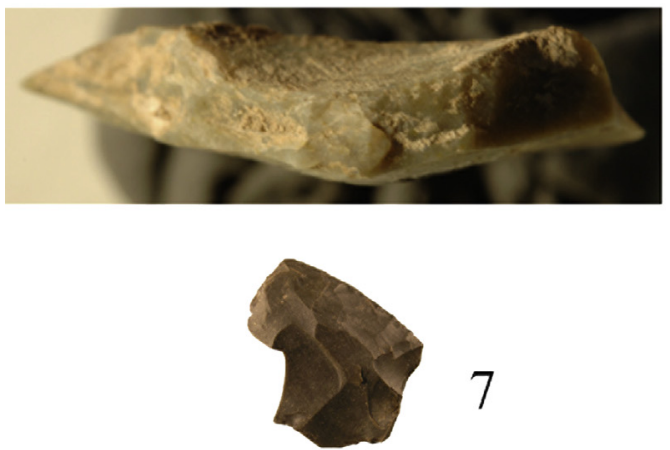

7

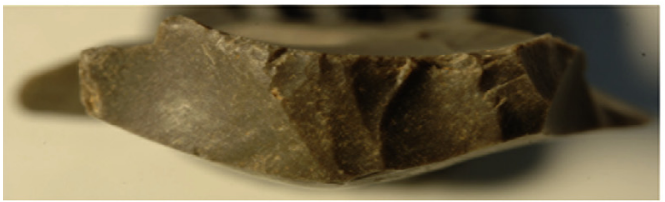

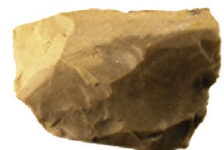

2
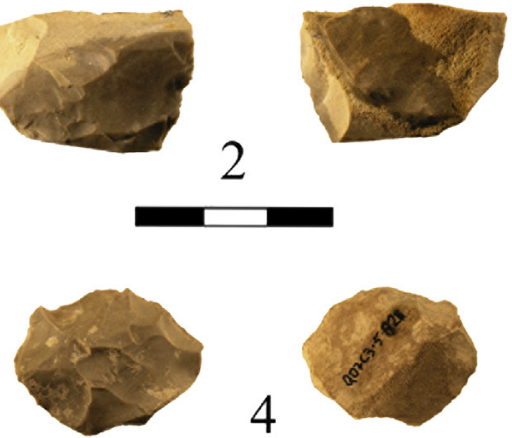

4
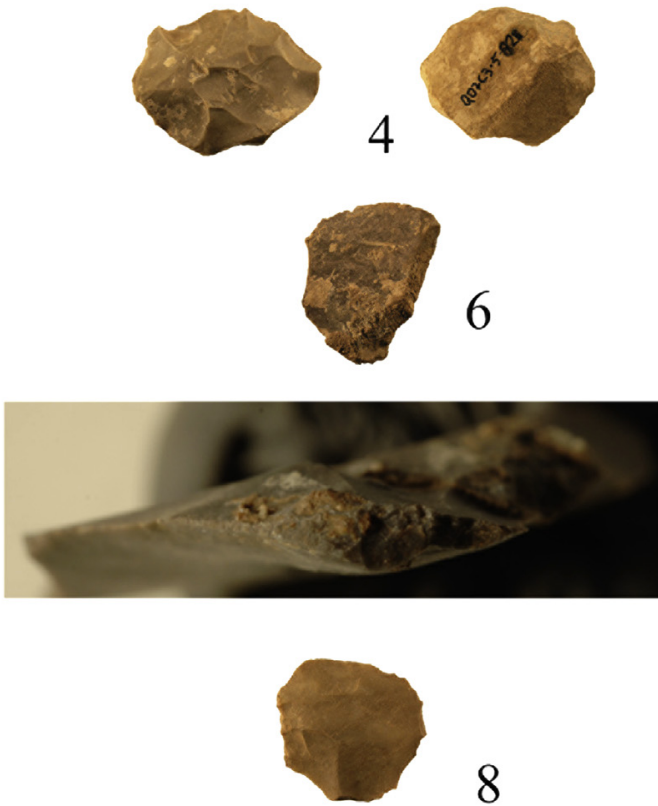

8

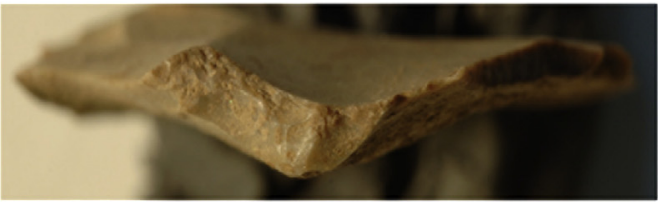

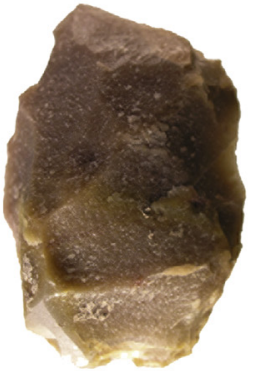

9

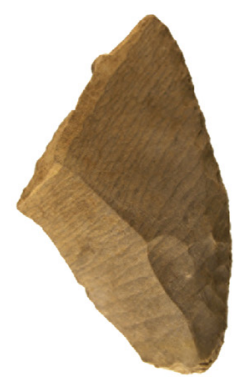

10

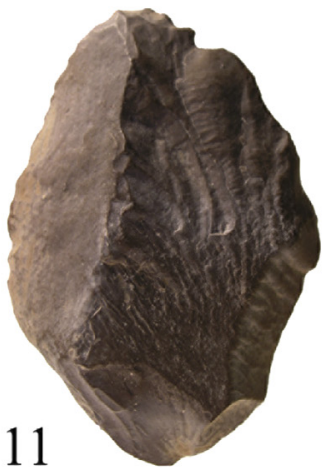

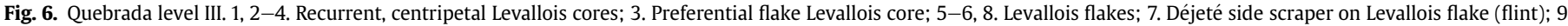

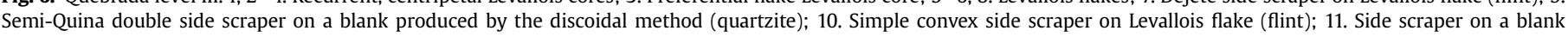
produced by the discoidal method (limestone).

assemblages, technological analysis suggests that small size was determined by the diminished volume of available raw-material. Use wear analysis of small flakes and small tools from several European LP sites shows a wide range of activities, including carcass processing and scraping and cutting of different materials (Brühl, 2003; Vergès, 2003). In the Iberian Peninsula record, this kind of production has been observed in Middle Pleistocene sites including Cuesta de La Bajada (Santonja Gómez et al., 2000) and Bolomor
(Fernández Peris, 2007) but it seems tightly related with the format of raw materials. This has been proposed for some Upper Pleistocene Middle Paleolithic sites in Italy (Kuhn, 1995). In the northern Iberian Peninsula, there is no evidence of systematic production of small flakes during Middle Pleistocene, as can be observed in Arlanpe, Lezetxiki, and Cueva Corazón (Rios-Garaizar et al., 2011; Sánchez Yustos et al., 2011; Arrizabalaga and Rios-Garaizar, 2012; Álvarez Alonso and Arrizabalaga, 2012). New data from the Levant 
Early Middle Paleolithic region suggest that the production of small flakes and even the implementation of ramified strategies were intensively developed in some sites such as Quesem (Barkai et al., 2010). For the European record, we can propose that small flake production and use was not so important in the overall organization of lithic toolkits during Early Middle Paleolithic. This implies that different productive processes (butchery, woodworking, etc.) were not so clearly structured in different phases, and precision activities probably were not so important. This has important implications for the understanding of technological evolution of Neandertal populations.

During the Upper Pleistocene Middle Paleolithic, the existence of ramified productions is significantly more important. Beside the aforementioned sites of Pech l'Azé and Roca des Bous, the production of diminutive Levallois was first described by Bordes in several sites from Southwestern France. Quina ramification strategies have been described in several sites. Les Tares, dated at the end of the Middle Pleistocene, shows the production and use of ramified Quina and Kombewa flakes (Geneste and Plisson, 1996). The Quina levels of Cova Negra and the Lower levels of Axlor are also probably situated in the Middle to Upper Paleolithic transition, and reveal Quina-like ramification processes (Bourguignon, 1997; Lazuén and González, 2015). In the Upper Pleistocene sites of Chez Pinaud and Les Pradelles in France, Quina ramified production involving the use of Quina resharpening flakes, sometimes retouched, has been documented (Bourguignon, 1997; Claud et al., 2012; Meignen 1988; Soressi, 2004; Costamagno et al., 2006).

The existence of clearly structured productive processes in the Late Middle Paleolithic suggest that work could have been divided among different agents inside the group, implying the existence of a social division of labor. This possibility has been discussed by Kuhn and Stiner (2006), almost only taking in account subsistence activities. Recent studies have widened the complexity and variability of subsistence strategies of Neandertal groups (SalazarGarcía et al., 2013; Sistiaga et al., 2014), previously seen as heavily dependent on large game (Bocherens, 2009). Also, other lines of evidence suggest that neandertals did not have a "low level of technological elaboration" as suggested by Kuhn and Stiner (2006). This can be seen in lithic technology organization (Turq et al., 2013), in the introduction of bone tools for manufacturing activities (Soressi et al., 2013; Mozota, 2014), in the use of pigments and minerals (Soressi and D'Errico, 2007), in the utilization of mastics and colles (Pawlik and Thissen, 2011), and the regular use of stone tipped hunting weapons (Villa and Lenoir, 2006; Villa et al., 2009; Rios-Garaizar, 2012b). The evidence of habitat structuring suggests that neandertals organized space to fulfill different kind of activities (Bourguignon et al., 2002; Conard and Adler, 1997; Vaquero et al., 2012). There is also other evidence of increasing social complexity, including the use of ornaments and body decoration (Finlayson et al., 2012; Peresani et al., 2013; Soressi and D'Errico, 2007; Zilhâo et al., 2010), and burials (Pettitt, 2002).

\section{Conclusions}

The ramification of production that can be understood as a systematic and predetermined recycling system is related both with the necessity to maximize raw material productivity but also with the search for small tools. The fabrication and use of small tools, not always using ramified productions, is one of the main features of Late Middle Paleolithic technological organization in the Iberian Peninsula. It is related with changes in productive processes that include new precision activities. These small tools are combined with other lithic implements to create a full range of lithic tools. The proximity to high quality raw material sources conditions the way that these small tools are obtained. In sites located far away from these sources, imported tools and flakes are recycled into cores for small flake production. In sites located closer to these raw material sources, small flakes are obtained through core reduction. Although small tool production and use is also present in the Lower and Early Middle Paleolithic in European assemblages, it is less systematic and usually is related to available raw material size.

\section{Acknowledgements}

V.V. and A.E's research is supported by the projects PROMETEO II/2013/016 and HAR2011-24878 "Paleolítico medio final y Paleolítico superior inicial en la región central mediterránea (Valencia y Murcia)". JRG developed part of this research in the Max Planck Institute of Leipzig with a Post-Doctoral Grant funded by the Basque Government. We want also to acknowledge all the participants in the Recycling Paleolithic meeting for fruitful discussions.

\section{References}

Altuna, J. 1989. La subsistance d'origine animal pendant le Moustérien dans la région Cantabrique (Espagne). In: Pathou, M., Freeman, L.G. (Eds.), L'Homme de Neandertal. La Subsistance, Actes Du Colloque International de Liège, vol. 6. ERAUL, Liège, pp. 41-43.

Altuna, J., Mariezkurrena, K., 2010. Tafocenosis en yacimientos del País Vasco con predominio de grandes carnívoros. Consideraciones sobre el yacimiento de Amalda. In: Baquedano, E., Rosell, J. (Eds.), Zona Arqueológica, No 13, Reunión de Científicos Sobre Cubiles de Hiena (y Otros Grandes Carnívoros) En Los Yacimientos Arqueológicos de La Península Ibérica (1. 2009. Alcalá de Henares). Vicepresidencia, Consejería de Cultura y Deporte y Portavocía del Gobierno. Museo Arqueológico Regional, Alcalá de Henares, pp. 214-228.

Altuna, J., Baldeón, A., Mariezkurrena, K., 1990. La cueva de Amalda (Zestoa, País Vasco). Ocupaciones paleolíticas y postpaleolíticas. In: Colección Barandiarán. Eusko Ikaskuntza, San Sebastián.

Álvarez Alonso, D., Arrizabalaga, Á., 2012. La secuencia estratigráfica inferior de la cueva de Lezetxiki (Arrasate, País Vasco). Una reflexión necesaria. Zephyrus 69, $15-29$.

Arrizabalaga, A., Rios-Garaizar, J., 2012. First human occupations in the Basque crossroad. World Prehistory 25, 157-181.

Barandiarán, J.M., 1980. Excavaciones en Axlor. 1967-1974. In: Barandiarán, J.M. (Ed.), Obras Completas de José Miguel de Barandiaran, Tomo XVII. La Gran Enciclopedia Vasca, pp. 127-384.

Barkai, R., Lemorini, C., Gopher, A., 2010. Palaeolithic cutlery 400 000-200 000 years ago: tiny meatcutting tools from Qesem Cave, Israel. Antiquty 084.

Bourguignon, L., 1992. Analyse du processus opératoire des coups de tranchet lateraux dans l'industrie moustérienne de l'Abri du Musée (Les-Eyziez-de-Tayac, Dordogne). Paléo 4, 69-89.

Bourguignon, L., 1997. Le Moustérien de type Quina: nouvelle définition dùne entinté technique. Universite Paris X Nanterre.

Bourguignon, L., 2001. Apports de l'experimentation et de l'analyse techno-morfofonctionelle à la reconnaisance de processus d'amenagement de la retouche Quina. In: Bourguignon, L., Ortega Cordellat, I., Frère-Sautot, M.-C. (Eds.) Préhistoire et Approche Expérimentale, Prehistoire 5Éditions Monique Mergoil, Montagnac, pp. 35-66.

Bourguignon, L., Sellami, F., Deloze, V., Sellier-Segard, N., Beyries, S., EmeryBarbier, E., 2002. L'Habitat Moustérien de La Folie (Poiters-Vienne): Synthèse des premiers resultats. Paléo 14, 29-48.

Bourguignon, L., Faivre, J.-P., Turq, A., 2004. Ramification des chaînes opératoires: une spécificité du Moustérien? Paléo 16, 37-48.

Bordes, F., 1981. Vingt-cinq ans aprés: le complexe moustérien revisité. Bulletin la Socièté Préhistorique Française 78, 77-87.

Brühl, E., 2003. The small flint tool industry from Bilzingsleben. In: Burdukiewicz, J.M., Ronen, A. (Eds.), Lower Palaeolothic Small Tools in Europe and Levant. BAR International Séries 1115, Oxford, pp. 65-92.

Burdukiewicz, J.M., Ronen, A., 2003. Lower Palaeolothic Small Tools in Europe and Levant. In: British Archaeological Reports International Series 1115. Oxford.

Carrión Santafé, E., Baena Preysler, J., Conde Ruiz, C., Cuartero Monteagudo, F., Roca, M., 2008. Variabilidad tecnológica en el musteriense de Cantabria. Treballs D'Arqueologia 14, 279-318.

Casanova, J., Mora Torcal, R., Martínez Moreno, J., de la Torre, I., 2008. Diversidad y continuidad de los sistemas técnicos del Paleolítico Medio en los Pirineos surorientales. In: Treballs d'Arqueologia; 2008 Núm. 14 Var. técnica del Paleolítico Medio en el sudoeste Eur. 14.

Castaños, P., 2005. Revisión actualizada de las faunas de macromamíferos del Würm antiguo en la Región Cantábrica. In: Montes Barquín, R., Lasheras Corruchaga, J.A. (Eds.), Actas de La Reunión Científica: Neandertales Cantábricos. Estado de La Cuestión. Ministerio de Cultura, Madrid, pp. 201-207.

Chiotti, L., 2000. Lamelles Dufour et grattoirs aurignaciens (carénés et à museau) de la couche 8 de l'abri Pataud, Les Eyzies-de-Tayac, Dordogne. L'Anthropologie 104, 239-263. 
Claud, É., Soressi, M., Jaubert, J., Hublin, J.-J., 2012. Étude tracéologique de l'outillage moustérien de type Quina du bonebed de Chez-Pinaud à Jonzac (CharenteMaritime). Nouveaux éléments en faveur d'un site de boucherie et de traitement des peaux. Gallia Préhistoire 54, 3-32.

Conard, N.J., Adler, D.S., 1997. Lithic Reduction and Hominid Behavior in the Middle Paleolithic of the Rhineland. Journal of Anthropological Research 53, 147-175.

Costamagno, S., Liliane, M., Cédric, B., Bernard, V., Bruno, M., 2006. Les Pradelles (Marillac-le-Franc, France): a Mousterian reindeer hunting camp? Anthropological Archaeology 25, 466-484.

Courty, M.-A., Carbonell, E., Vallverdú Poch, J., Banerjee, R., 2012. Microstratigraphic and multianalytical evidence for advanced Neanderthal pyrotechnology at Abric Romani (Capellades, Spain). Quaternary International 247, 294-312.

Dibble, H.L., McPherron, S.P., 2006. The Missing Mousterian. Current Anthropology 47, 777-803.

Eixea, A., 2012. Aprovechamiento de las calizas en el Paleolítico medio del Abrigo de la Quebrada (Chelva, Valencia). Archivo de Prehistoria Levantina 29, 53-64.

Eixea, A., Roldán, C., Villaverde, V., Zilhão, J., 2014a. Middle Palaeolithic flint procurement in Central Mediterranean Iberia: implications for human mobility. Lithic Studies 1.

Eixea, A., Villaverde, V., Zilhão, J., 2011. Aproximación al aprovisionamiento de materias primas líticas en el yacimiento del Paleolítico medio del Abrigo de la Quebrada (Chelva, Valencia). Trabajos de Prehistoria 68, 65-78.

Eixea, A., Villaverde, V., Zilhão, J., Sanchis, A., Morales, J., Real, C., Bergadà, M., 20112012. El nivel IV del Abrigo de la Quebrada (Chelva, Valencia). In: Análisis microespacial y valoración del uso del espacio en los yacimientos del Paleolítico medio valenciano, XXXIII. Mainake, pp. 127-158.

Eixea, A., Villaverde, V., Zilhão, J., Bergadà, M., Sanchis, A., Morales, J., Real, C., Martínez, J.A., 2014b. Variation in the use of space throught time at Abrigo de la Quebrada (Chelva, Valencia). The case of Middle Paleolithic levels IV and VII. In: Debating Spatial Archaeology: International Workshop on Landscape and Spatial Analysis in Archaeology. June 2012, Santander, pp. 153-166.

Fernández Peris, J., 2007. La Cova del Bolomor (Tavernes de la Valldigna, Valencia). In: Las industrias del Pleistoceno medio en el ámbito del Mediterráneo peninsular. Serie de Trabajos Varios del SIP, 108. Valencia.

Finlayson, C., Brown, K., Blasco, R., Rosell, J., Negro, J.J., Bortolotti, G.R., Finlayson, G., Sánchez Marco, A., Giles Pacheco, F., Rodríguez Vidal, J., Carrión, J.S., Fa, D.A., Rodríguez Llanes, J.M., 2012. Birds of a Feather: Neanderthal exploitation of Raptors and Corvids. PLoS One 7, e45927.

Finlayson, C., Fa, D.A., Jiménez Espejo, F., Carrión, J.S., Finlayson, G., Giles Pacheco, F., Rodríguez Vidal, J., Stringer, C., Martínez Ruiz, F., 2008. Gorham's Cave, Gibraltar - the persistence of a Neanderthal population. Quaternary International 181, $64-71$.

Garcia Garriga, J., Martínez Molina, K., Baena Preysler, J., 2012. Neanderthal survival in the North of the Iberian Peninsula? Reflections from a Catalan and Cantabrian Perspective. Journal World Prehistory 25, 81-121.

García-Moreno, A., Rios-Garaizar, J., Marín Arroyo, A.B., Ortiz, J.E., Torres, T., LópezDóriga, I., 2014. La secuencia musteriense de la Cueva del Niño (Aýna, Albacete) y el poblamiento neandertal en el Sureste Peninsular. Trabajos de Prehistoria (in press)

Geneste, J.-M., Plisson, H., 1996. Production et utilisation de l'outillage lithique dans le moustérien du Sud-Ouest de la France: Les Tares à Sourzac, Vallé de l'Isle. Dordogne. Quaternaria Nova VI, 343-367.

González Urquijo, J.E., Ibáñez Estévez, J.J., Ríos Garaizar, J., Bourguignon, L., 2006. Aportes de las nuevas excavaciones en Axlor sobre el final del Paleolítico Medio. In: Cabrera Valdés, V., Bernaldo de Quirós, F., Maíllo, J.M. (Eds.), Ante El Centenario de La Cueva de El Castillo: El Ocaso de Los Neandertales. UNED, Santander, pp. 269-291.

González Urquijo, J.E., Ibáñez Estévez, J.J., Rios-Garaizar, J., Bourguignon, L., Castaños Ugarte, P., Tarriño Vinagre, A., 2005. Excavaciones recientes en Axlor. Movilidad y planificación de actividades en grupos de neandertales. In: Montes Barquín, R., Lasheras Corruchaga, J.A. (Eds.), Actas de La Reunión Científica: Neandertales Cantábricos. Estado de La Cuestión. Ministerio de Cultura, Madrid, pp. 527-539.

Higham, T., Compton, T., Stringer, C., Jacobi, R., Shapiro, B., Trinkaus, E., Chandler, B., Groning, F., Collins, C., Hillson, S., O'Higgins, P., FitzGerald, C., Fagan, M., 2011. The earliest evidence for anatomically modern humans in northwestern Europe. Nature 479, 521-524.

Kuhn, S.L., 1995. Mousterian Lithic Technology: an Ecological Perspective. Princeton University Press, Princeton.

Kuhn, S.L., Stiner, M.C., 2006. What's a mother to do? The division of labor among Neandertals and modern humans in Eurasia. Current Anthropology 47, $953-980$.

Lazuén, T., González-Urquijo, J., 2015. Recycling in the Early Middle Paleolithic: the role of resharpening flakes assessed through techno-functional analysis. Quaternary International 361, 229-237.

Mallol, C. Hernández, C.M., Cabanes, D. Sistiaga, A., Machado, J., Rodríguez, Á. Pérez, L., Galván, B., 2012. The Black Layer of Middle Palaeolithic combustion structures. Interpretation and Archaeostratigraphic implications. Journal of Archaeological Science 40, 2515-2537.

Martínez-Moreno, J., Mora, R., Ignacio de la, T., 2010. The Middle-to-Upper Palaeolithic transition in Cova Gran (Catalunya, Spain) and the extinction of Neanderthals in the Iberian Peninsula. Journal of Human Evolution 58, 211-226.

Meignen, L., 1988. Un exemple de comportement technologique diférentiel selon les matières premières: Marillac, couches 9 et 10. In: Otte, M. (Ed.), Homme de Néandertal, vol. 4. LaTechnique. E.R.A.U.L, Liège, pp. 71-79.
Montes, L., Utrilla, P., Hedges, R., 2001. Le passage Paléolithique MoyenPaléolithique Supérieur dans la Vallée de l'Ebre (Espagne). Datations radiométriques des grottes de Peña Miel et Gabasa. In: Zilhão, J., Aubry, T. Carvalho, A.F. (Eds.), Les Premiers Hommes Modernes de La Péninsule Ibérique: Actes Du Colloque de La Commission VIII de l'UISPP. Instituto portuguès de arqueologia, Lisboa.

Mora, R., De la Torre, I., Martínez-Moreno, J., 2004. Middle Palaeolithic mobility and land use in the Southwestern Pyrenees: the example of Level 10 in La Roca dels Bous (Noguera, Catalunya, Northeast Spain). In: Conard, N.J. (Ed.), Settlement Dynamics of the Middle Paleolithic and Middle Stone Age, vol. II. Kerms Verlag, Tübingen, pp. 415-435.

Mozota, M., 2012. El hueso como materia prima: El utillaje óseo del final del Musteriense en el sector central del norte de la Península Ibérica. Universidad de Cantabria.

Mozota, M., 2014. Los útiles óseos "poco elaborados" en el Paleolítico inferior y medio y su continuidad en el Paleolítico superior. Una revisión historiográfica. Complutum 25, 17-33.

Navazo, M., Díez, J.C., 2009. Prado vargas y la variabilidad tecnológica al finales de Paleolítico Medio en la meseta norte. Treballs D'Arqueologia 14,121-139.

Pawlik, A., Thissen, J., 2011. Hafted armatures and multi-component tool design at the Micoquian site of Inden-Altdorf, Germany. Journal of Archaeological Science 38, 1699-1708.

Peresani, M., Vanhaeren, M., Quaggiotto, E., Queffelec, A., d'Errico, F., 2013. An Ochered Fossil Marine Shell from the Mousterian of Fumane Cave, Italy. PLoS One 8, e68572.

Pettitt, P., 2002. The Neanderthal dead: exploring mortuary variability in Middle Palaeolithic Eurasia. Before Farming 2002/1, 19.

Rios-Garaizar, J., 2005. Características de la producción lítica al final del Paleolítico Medio en el País Vasco. El caso del nivel B de Axlor (Dima, Bizkaia). In: Montes Barquín, R., Lasheras Corruchaga, J.A. (Eds.), Actas de La Reunión Científica: Neandertales Cantábricos. Estado de La Cuestión, Monografías Del Museo Nacional Y Centro de Investigación de Altamira No 20. Ministerio de Cultura Madrid, pp. 333-348.

Rios-Garaizar J. 2008. Variabilidad tecnológica en el Paleolítico Medio de los Pirineos Occidentales: una expresión de las dinámicas históricas de las sociedades neandertales. Treballs D'Arqueologia 14, 172-195.

Rios-Garaizar, J., 2010. Organización económica de las sociedades Neandertales: el caso del nivel VII de Amalda (Zestoa, Gipuzkoa). Zephyrus LXV, 15-37.

Rios-Garaizar, J., 2012a. Industria lítica y sociedad en la Transición del Paleolítico Medio al Superior en torno al Golfo de Bizkaia. PUbliCan - Ediciones de la Universidad de Cantabria, Santander.

Rios-Garaizar, J., 2012b. Técnicas de caza en el Paleolítico Medio del País Vasco. Isturitz Cuadernos de la Sección de Prehistoria y Arqueología 12, 7-37.

Rios-Garaizar, J., Garate, D., Gómez-Olivencia, A., Iriarte-Avilés, E., AranburuArtano, A., Arceredillo-Alonso, D., García, A., Iriarte-Chiapusso, M.J., Moreno, J. Murelaga, X., Ortíz, J.E., Torres, T., San Pedro-Calleja, Z., Zapata-Peña, L., 2011. The Lower to Middle Palaeolithic transition in northern Iberia: new data from Arlanpe Cave. Antiquity 85.

Ruebens, K., 2013. Regional behaviour among late Neanderthal groups in Western Europe: a comparative assessment of late Middle Palaeolithic bifacial tool variability. Journal of Human Evolution 65, 341-362.

Salazar-García, D.C., Power, R.C., Sanchis Serra, A., Villaverde, V., Walker, M.J., Henry, A.G., 2013. Neanderthal diets in central and southeastern Mediterranean Iberia. Quaternary International 318, 3-18.

Sánchez Yustos, P. Díez-Martín, F., Díaz Muñoz, I.M., Gómez de la Rúa, D., Gómez González, J.Á., 2011. Estrategias de talla en Cueva Corazón (Mave, Palencia). Un yacimiento del Musteriense Antiguo en las estribaciones meridionales de la Cordillera Cantábrica. Trabajos de Prehistoria 68, 51-63.

Sanchis, A., Morales, J.V., Real, C., Eixea, A., Villaverde, V., Zilhão, J., 2013. Los conjuntos faunísticos del Paleolítico medio del Abrigo de la Quebrada (Chelva, Valencia): problemática de estudio, metodología aplicada y síntesis de los primeros resultados. In: Sanchis, A., Pascual, B. (Eds.), Animals i arqueologia hui. I Jornades d'arqueozoologia. Museu de Prehistòria de València, pp. 65-82.

Santonja Gómez, M., Pérez González, A., Villa, P., Sesé, C., Soto, E., Mora Torcal, R. Eisenmann, V., Dupré, M., 2000. El yacimiento paleolítico de Cuesta de la Bajada. In: Balbín, R., Bicho, N., Carbonell, E., Hockett, B., Moure Romanillo, A. Raposo, L., Santonja Gómez, M., Vega, G. (Eds.), Paleolítico Da Península Ibérica. ADECAP, Porto, pp. 169-187.

Sistiaga, A., Mallol, C., Galván, B., Summons, R.E., 2014. The Neanderthal meal: a new perspective using faecal biomarkers. PLoS One 9, e101045.

Soressi, M., 2004. L'industrie lithique des niveaux moustériens de Chez-Pinaud à Jonzac (Charentes), fouilles 1998-99. Aspects taphonomiques, économiques et technologiques. Préhistoire du Sud-Ouest (Suppl. 8), 79-95.

Soressi, M., D'Errico, F., 2007. Pigments, gravures, parures: les comportement symboliques controversés des Néandertaliens. In: Vandermeersch, B. Maureille, B. (Eds.), Les Néandertaliens, Biologie et Cultures, Documents préhistoriques 23. C.T.H.S., Paris, pp. 297-309.

Soressi, M., McPherron, S.P., Lenoir, M., Dogandžić, T., Goldberg, P., Jacobs, Z. Maigrot, Y., Martisius, N.L., Miller, C.E., Rendu, W., Richards, M., Skinner, M.M. Steele, T.E., Talamo, S., Texier, J.-P., 2013. Neandertals made the first specialized bone tools in Europe. Proceedings of the National Academy of Sciences 110 $14186-14190$.

Tarriño Vinagre, A., 2006. El sílex en la cuenca Vasco-Cantábrica y Pirineo Navarro Monografias del Mueso Nacional y Centro de Investigación de Altamira. Ministerio de Cultura, Madrid. 
Torre de la, I., Martínez-Moreno, Jorge, Mora, R., 2013. Change and stasis in the Iberian Middle Paleolithic: considerations on the significance of Mousterian technological variability. Current Anthropology 54, S320-S336.

Turq, A., Roebroeks, W., Bourguignon, L., Faivre, J.-P., 2013. The fragmented character of Middle Palaeolithic stone tool technology. Journal of Human Evolution 65, 641-655.

Utrilla, P., Vilchez, J., Montes, L., Barandiarán, I., Altuna, J., Gil, E., López, P., 1987. La cueva de Peña Miel. Nieva de Cameros, La Rioja. In: Excavaciones arqueológicas en España. Ministerio de Cultura. Dirección General de Bellas Artes y Archivos. Subdirección General de Arqueología y Etnología, Madrid.

Uzquiano, P., Yravedra, J., Zapata, B.R., Gil Garcia, M.J., Sesé, C., Baena, J., 2012. Human behaviour and adaptations to MIS 3 environmental trends ( $>53-30 \mathrm{ka} \mathrm{BP}$ ) at Esquilleu cave (Cantabria, northern Spain). Quaternary International 252, 82-89.

Vaquero, M., Chacón, Ma . G., Cuartero, F., García-Antón, Mª. D., Gómez de Soler, B., Martínez, K., 2012. The lithic assemblage of level J. In: Carbonell i Roura, E. (Ed.), High Resolution Archaeology and Neanderthal Behavior, Vertebrate Paleobiology and Paleoanthropology. Springer Science+Business Media B.V. http:// dx.doi.org/10.1007/978-94-007-3922-2_7.

Vergès, J.M., 2003. Caracterització des models d'instrumental lític de mode 1 a partir de les dades de l'anàlisi funcional dels conjunts litotènics d'Aïn Hanech El-Kherba (Algèria), Monte Poggiolo i Isernia la Pineta (Itàlia). Universitat Rovira i Virgili.

Villa, P., Boscato, P., Ranaldo, F., Ronchitelli, A., 2009. Stone tools for the hunt: points with impact scars from a Middle Paleolithic site in southern Italy. Journal Archaeological Science 36, 850-859.

Villa, P., Lenoir, M., 2006. Hunting weapons of the Middle Stone Age and the Middle Palaeolithic: spear points from Sibudu, Rose Cottage and Bouheben. South African Humanities 18, 89-122.
Villaverde, V., 1984. La Cova Negra de Xàtiva y el Musteriense de la región central del Mediterráneo español. In: Trabajos Varios del Servicio de Investigación Prehistórica 79. Valencia.

Villaverde, V., Eixea, A., Rios-Garaizar, J., Zilhão, J., 2012. Importancia y valoración de la producción microlevallois en los niveles II y III del Abrigo de la Quebrada (Chelva, Valencia). Zephyrus 69, 13-32.

Villaverde, V., Eixea, A., Zilhâo, J., 2008. Aproximación a la industria lítica del Abrigo de la Quebrada (Chelva, Valencia). Treballs D'Arqueologia 14, 213-228.

Wood, R.E., Arrizabalaga, A., Camps, M., Fallon, S., Iriarte-Chiapusso, M.-J., Jones, R. Maroto, J., de la Rasilla, M., Santamaría, D., Soler, J., Soler, N., Villaluenga, A., Higham, T.F.G., 2014. The chronology of the earliest Upper Palaeolithic in northern Iberia: new insights from L'Arbreda, Labeko Koba and La Viña. Journal of Human Evolution.

Wood, R.E., Barroso-Ruíz, C., Caparrós, M., Jordá Pardo, J.F., Galván Santos, B., Higham, T.F.G., 2013. Radiocarbon dating casts doubt on the late chronology of the Middle to Upper Palaeolithic transition in southern Iberia. Proceedings of the National Academy of Sciences.

Yravedra Sainz de los Terreros, J., 2003. Estado de la cuestión sobre la subsistencia del Musteriense en el interior y la fachada de la Península Ibérica. Zephyrus 56, $61-84$.

Zilhão, J., 2006. Chronostratography of the Middle-to-Upper Paleolithic Transition in the Iberian Peninsula. Pyrenae 37, 7-84.

Zilhâo, J., Angelucci, D.E., Badal-García, E., d'Errico, F., Daniel, F., Dayet, L., Douka, K. Higham, T.F.G., Martínez-Sánchez, M.J., Montes-Bernárdez, R., MurciaMascarás, S., Pérez-Sirvent, C., Roldán-García, C., Vanhaeren, M., Villaverde, V., Wood, R., Zapata, J., 2010. Symbolic use of marine shells and mineral pigments by Iberian Neandertals. Proceedings of the National Academy of Sciences 107, 1023-1028. 